\title{
The Concept of Islamic Education in Strengthening Children's Independence
}

\author{
Rita Hartati ${ }^{1}$, Samwil Samwil ${ }^{1}$, Sulaiman Ali $^{1}$ \\ ${ }^{1}$ Faculty of Engineering, Universitas Teuku Umar, Indonesia, Email: RH: ritahartati@utu.ac.id, SS: \\ samwil@utu.ac.id, SA: sulaimanali@utu.ac.id
}

Submitted: 22/04/2020 Revised: $12 / 05 / 2020 \quad$ Accepted: 19/05/2020

How to cite this article: Hartati, R., Samwil, S., \& Ali, S. The concept of Islamic education in strengthening children's independence. IJELR: International Journal of Education, Language, and Religion, 2(1), 17-24. https://doi.org/10.35308/ijelr.v2i1.2192

\begin{abstract}
This article aims to discuss the basic concept of strengthening children's independence within the paradigm of Islamic education. Specifically, this study focuses on the child's self-reliance factors, the method, and the benefits of strengthening children's independence according to the concept of Islamic education. We argue that self-independence is important for children future life. It affects the mentality and the quality of upbringing that determines the ability of the child. Parents should be able to build and ensure that the parental values are infused within children belief system as a capital in their next life. Among the many methods of strengthening children's independence are Targhip and Tarhib. These methods is generally about letting the child to take part in the decision making process.
\end{abstract}

\section{Keywords}

children independence; Islamic education; attitude

\section{Introduction}

Child self-reliance is a matter or circumstance in which he or she can stand alone without relying on others (Department of national Education, 2007). The above definition needs to be explained further because in reality there is no human being that is able to live alone without relying on others. Humans are social creatures that cannot be separated from their social life. They connect attitudes, behavior and deeds of each other.

Self-reliance needs to be grown in children starting from an early age because with self-reliance, the child will be more prone to overcome all the problems that he or she will face someday without depending on the other person, whether it is a problem that believes in personal life or problems related to the workplace. In these days, a competitive workforce in need of strong personal and self-reliant individuals can indirectly determine whether or not a person is successful in gaining dreams. Child independence can be trained by parents as the closest person to the child. Parents can do a number of things to train and to grow their children's life from an early age. 
The process of education in Islam has the aim to give birth to a new generation with all its excellence and civilized. The creation of this generation is done with sincerity and full sincerity and completely to Allah SWT through the process of Tarbiyah. Through this process of Tarbiyah, Allah SWT has been presenting Muslim who is Uswah and Qudwah through Muhammad SAW. Islam requires a thorough education program, both the worldly aspects and ukhrowi. So this, the educational process is strongly supported by many aspects, especially teachers or educations of parents, and also the environment. With the hope that children can achieve educational objectives as expected; The perfect adult.

According to Conger (1997), many children are considered not independent even the child is impressed. Being a parent is not an easy job. That work requires wisdom, diligence, and patience. There is no easy term in parenting, so there are some skills that parents need to foster children's independence. Surely those skills should be able to appeal to children effectively. Naturally, children have the urge to be independent. They are sometimes more than happy to be able to take care of themselves than served. Unfortunately, parents often inhibit desire and encouragement for self-reliant although some children are able to carry out everything independently. So, in this case the question for us is how to cultivate child independence based on the concept of Islamic education.

\section{The Basic of Islamic Education}

The first surah in the Qur'an revealed to the Prophet Muhammad Peace Be Upon Him (PBUH) does not begin with orders relating to other things, such as special worship and others, but begins with the commandment related to study the letter or reading (Saleh, 1994). According to the word of Allah SWT in the Qur'an:

"Read by (mentioning) the name of your lord creating. He has created man from a clot of blood. Read, and the gracious Lord. Who teaches (human) by parcel of Kalam. He teaches man what he does not knew" (Al-'Alaq: 1-5).

The verse above is the first verse down in Makkah to explain the virtue of Allah to create a man from the weak so that he becomes strong by exposing the demands or obligation to read and write, which will be the difference between humans and other creatures.

According to Al-Ghazali (1997) The purpose of Islamic education is as the following:

1. The main purpose of education is the establishment of morality, the virtue of soul, sexual glory and strong personality are the main objectives and education for the survival of Muslims, because morality is a fundamental aspect in the life of a person, society and a country.

2. The purpose of education is to achieve the happiness of world and hereafter. God's created man is to always serve him.

Islamic education is educating people to be able to live a happy world and the hereafter. Because the teachings of Islam contain about the living that encompasses all aspects of human life. Furthermore, the objective of Islamic education is identical with the purpose of life. In general, the Qur'an is expressed in his word which means:

"And I (Allah) have not made a genie and a man, but to worship me" (Adzariyat: 56).

Marimba (1974), stated that the final goal of Islamic education was the formation of Muslim personalities. As for the personality that is the whole aspek-aspeknya good behavior of the activities of his soul and his philosophy and his belief shows devotion to God, and surrender to him (Ahmadi, 2001). Furthermore, to enslave Allah SWT to seek the Illahi Keredhaan is the general purpose of the treatise, thus it is a general purpose that is to be achieved by education and teaching of Islam. These general objectives can be described in three aspects: 
- Perfecting human relationships with the

- Perfecting human relationships with others

- Create balance, harmony and harmony between relationship with God and relationship with fellow human beings.

The third embodiment of the above description in one's self is only possible with mastery of science. Without science means a person is not ready or not worthy to bear the title of God's servant. Thus the science referred to here is a science of religion that can establish itself as a servant of God to achieve the God's life in the lives of the World and the Hereafter (Ahmadi, 2001). The purpose of Islamic religious education is to build a religious human, which means that humans are able to carry out the teachings of Islam well and perfectly, so that it is reflected in attitudes and actions in all of his life, in order to achieve the happiness of life and the glory of life of the world and the hereafter.

Islamic education is very important and foremost for every Muslim man, because only with the education of human religion can obtain the happiness of life in the world and the hereafter. That happiness can be gained by every human being when it can enhance human relationships with the same, can enhance human relationships with others. And able to realize the balance, harmony, and harmony between relationship with God and relationship with fellow man. It can be realized through Islamic religious education as a basis to perform it perfectly and the establishment of Allah SWT.

According to the understanding of the Qur'an educating and demanding that science is one of worship, with the existence of worship, people are increasingly close to the relationship with Allah SWT and always draw closer to him. Allah SWT prioritizes servants who are knowledge of the speed in comparison with the foolish Servant as the word of Allah SWT:

"O Believers when you are said to you, "be in the council", so that God will not give you space. And when it is said: "Stand ye", then stand, and Allah will exalt those who believe among you and those who are given some degree of science. And Allah knows what you do" (Al-Mujadilah: $11)$.

With the knowledge of human beings can do the worship of God perfectly, the science given by God should be used properly and not to violate or corrupt the moral and faith with what has been obtained. Based on the paragraph description above can be taken a conclusion that the basis of Islamic education is the Qur'an and Hadist, which aims to form the man of God who is muttaqin and capable, and realize the happiness of the world and the hereafter.

\section{Discussion}

\section{Strategies to Strengthening Children' Independence}

Strategy is a way to be pursued by a person to reach a certain purpose, either in the corporate or business environment, or in the satisfaction of other sciences (Arief, 2002). Teaching methods or ways that teachers use in teaching Islamic educational subjects to students. The kinds of methods used in religious teaching are methods of lectures, discussions, demonstrations, Sociodrama, Driil and questions and answers.

Teaching methods in Islamic education are as the following:

a. Lecture methods

The lecture method is given when a material requires explanation so that the material is understood by the person. Lectures are the most classical method, but they are still used by people until now. 
b. Discussion methods

Discussions are processes involving two or more individuals, verbal integration and dealing with each other, information sharing, maintaining a self-maintenance in solving a particular problem (problem solving). While the method of discussion in the learning process is a way of studying the materials or conveying the material with the way to discuss it, in order to create understanding and change of behavior in students.

c. Demonstration method

The method of Demodtration is the teaching method using demonstration tools, to clarify a sense of understanding. Or how to demonstrate how to do and the course of a certain process of making to students. To Show or introduce/To bring (Joseph, 1995).

d. Sociodramatic method

In religious education The method of Sociodrama is effective in presenting sexual lessons, history and other topics. In historical material, for example, the teacher describes the story of the Caliph Abu Bakar when he entered Islam. The story is certainly interesting if presented through Sociodrama (Yusuf, 1995).

e. Drilling method

Drill method is a way of presenting the materials with the road/How to train the students to master the lesson and skilled in carrying out the task of training given. At Driil (exercise ready) to perform prayer worship in Islam is strongly emphasized in the students as early as possible so that with exercises done in the students do not feel awkward after they mature.

f. Question and answer method

In Tafseer al-Munar quoted by Abdurrahman An-Nahlawi stated that the counsel has several important forms and concepts that are, giving advice in the form of explanations about the truth and the interests of things with the purpose of people given the advice will be abated, the giving of advice should describe the advice that can stir the feelings of effation and emotion, such as warnings through death Then the expected impact of the method of Mauizah is to awaken feelings of divinity in the soul of the students, raising the firmness to always hold to the mind of the Godhead, hold to the congregation of faith, most importantly is the creation of clean and sacred private (Abdurrahma, 1994). Advice occupies a high position in religion because religion is naehat, it is revealed by the Prophet Muhammad until three times when giving lessons to his companions. In addition should pay attention to ways of delivering and giving advice, giving advice should be adjusted to the situation and conditions, education should always be patient in delivering advice and not feeling bored/discouraged.

g. Transparency Method

It is an effective method of Islamic education applied by a teacher in the education process. Because the education of the example will affect the individual in habits, behaviors and attitudes. In the Qur'an the word for example is project with the word Uswah which is then given the nature behind it as a good-hearted nature. So there is an expression of Uswatun Hasanah that has a good example. The words of this uswah in the Qur'an are repeated three times by taking samples on the prophets, namely the Prophet Muhammad SAW, the Prophet Ibrahim, and the believers who are steadfast to God (Nata, 1997).

Children are beings who love to emulate. His parents were figures and idols. When they see the good habits of his mother's father, they will quickly take an example. Poor parents of attitudes will be imitated by children. Children are also easiest to follow the words that come out of the mouths of parents. Rasulullah SAW sometimes gave counsel directly to the children (Fathoni, 2008). 
In fact the childhood phase is the most suitable, the most long, and most important phase for an educator cultivating good principles, straight and righteous direction into the soul and attitudes of his children. The opportunity for it is wide open, supported by the modern facilities and infrastructures that are adequately available in each educational institution on one side. On the other hand, considering this phase the children still have sacred gifts, clean souls, clear talents, and Hearts have not contaminated the dust of sin and poverty. Basically, people tend to need exemplary and role models that are able to direct the right path and as well as a dynamic parable that explains how to practice God's sharpener. Therefore, God sent his apostles to explain the various sharia through the example (Abdurrahman, 1995).

In everyday life we can witness the religious actions committed by children they essentially gain from imitating. Pray, for example, they perform the results of seeing deeds in the environment, either habituation or intensive teaching. "The experts think that in all things the children are a master imitation". The imitation of this nature is a positive method of religious education in children (Ramayulis, 2010). If we come back to the history that the prophet in his life always give a good example to his friends through his or her deeds, whether his speech or deed, so that he was blessed with his chastity, he got the nickname $\mathrm{Al}$ Amin, and it was recognized both his friends and opponents. The example of the Prophet is the forerunner of the establishment of an approach/method of Islamic education that until today is still actual. This method can enter formal, informal (family) and non-formal education areas. In addition, the transparency can also be demonstrated in the attitude and attitudes of educators and educational personnel in providing examples of good action so it is hoped to be a role model for learners to sample. The demonstrators of various exemplary examples are preliminary steps of habituation, if the educators and other educations require that the learners behave and be in accordance with the values of the character, then the educators and education professionals are the first and foremost people give examples of how to behave and be in accordance with those values. For example, dress neatly, come on time, work hard, speak polite, compassion, attention to learners, honest, maintain cleanliness and so on (Gunawan, 2014).

So the teacher's example is a person who is worthy of being imitated by the teacher, the teacher here can also be referred to as the exemplary subject or the person exemplified by the learner. So being an example is part of a teacher, so being a teacher means accepting responsibility to be an example. Of course personal and what the teacher is doing will be highlighted by the students and people around his ward, so the teacher must demonstrate the best example and perfect moral (Munir, 2016).

Strategies in strengthening children' independence are as the following:

\section{Exemplary method}

Educating with examples is one of the learning strategies that is considered to be a big influence, this has been proved by the prophet Muhammad SAW. As a result, whatever is being taught can be received immediately from within the family and by its followers, he will penetrate their heart. All that is exemplified by the Prophet in life is a reflection of the content of the Qur'an and as a whole should be followed and exemplary.

The method of Islamic education is the most effective and efficient method of shaping the child's personality. The educator's position as a good example of his children will be imitated in various sayings and attitudes. The example of being a factor determines the poor nature of the child. If educators are honest, trustworthy, courageous, brave, abstain from deeds contrary to religious teachings, then the child will grow honesty, formed with noble morality and others (Hidayati, 2013).

\section{Targhip and Tarhib}

Targhib which contains the meaning of hope to gain pleasure, love and happiness. Targhib is defined as a promise accompanied by persuasion and seduction to delay the welfare of delicacy and enjoyment but the delay is certainly good and pure and done through righteous charity, or from the harmful delights (bad work). This is done to seek the goodness of Allah and it is the mercy of Alllah SWT for 
his servant. Furthermore, the Tarheeb is interpreted by terminology to be a threat or intimidation through the punishment caused by the implementation of a sin, error, or deed that God has forbidden. Targhib and Tarheeb are based on the fitrah given by God SWT to mankind, such as desire, strength, enjoyment, pleasures of life, and good everlasting joy and fear of anguish misery and bad end.

In Islamic education Al Targheeb method is a way by educators to give motivation to do and love goodness and seduction to do righteous charity and give urgency of goodness itself. So that the students do sincerely in hopes of obtaining reward or reward from Allah SWT. The substance of Al Targheeb method is to motivate oneself to do good. Whether self-motivating is growing because of extrinsic or external influences, as well as the instrinsik factor or factors within the learners. Have a strong suggestion for learners to create dreams. Similarly, the descriptions given by educators about the success of a smart and vigorous learning, or the experience of life around a student environment, good and bad experiences, will also contribute to the size of motivation that the soul of a student has.

Furthermore, it means that a big and small motivation is influenced by how the environment, social pattern, community behaviour, comfort in the family. In accordance with the concept of education, where the community around the school, the parents and the school itself, where in it applies the law of causality which between one and the other it has a binding alignment in the common purpose of the process of teaching learning outcomes in good education and quality. While the Tarheeb method is interpreted as a means used in Islamic education in the form of submission of punishment or threat of violence again with various other methods that are more malleable.

With this method the students are expected to be deterrent and leave negative things because they fear the threats and the punishment will be received from both parents, teachers and threats from God someday in the Hereafter.

\section{Parable Method (Amtsal)}

The parable is done by Rasulullah SAW, as one of the learning strategies to give understanding to the object of educational materials target as easy as possible, so that the content of the purpose of the lesson material can be digested properly, this strategy is done by means of something with something that Alin, draw closer to something abstract with a more concrete.

The parable used by the prophet as one of the learning strategies is always a condition of meaning that can actually bring something abstract to the concrete or make something still vague in the meaning of being something very clear.

In raising self-reliance on children, it may not go as we expect. Many of the obstacles we face as a developmental barrier in all, may not go as we would expect. Many of the obstacles we face are as a developmental barrier in all things to the child. The home environment is a very important environment in terms of children's activities. In various ways the school is a home environment Suplem. Thus the integration between home and school is very important (Clemes, 2001).

In fact the family environment or home environment is not always able to provide a good experience for child development, especially for single children many obstacles faced. These constraints include:
a. Anxiety
b. The likelihood of depression
c. Hostile attitudes toward children and others
d. Sleep disorders, restlessness, delirious, nightmares
e. Eating disorders, e.g. appetite is greatly decreased
f. Parents are too busy with their work
g. Unfulfilled needs or children's play facilities
h. Children who are too stubborn 
i. Health and nutrition for children who are far from enough

j. Low economic chilling or poverty

k. An environment that is less supportive for child development.

1. Demands for child's life are not met.

As a busy parent, we have to spend time on children because they will have an impact on the development of the child. If a child is at school meetings, preferably as a parent, we should attend each meeting so very important for a reason.

\section{The Benefits of Strengthening Children's Independence}

Among the benefits of raising the child's independence in the concept of Islamic education is to form the personality of Islam, master Tsaqofah Islam, Mastering Science and Technology (IPTEK), and possess adequate skills.

1. Shaping the Islamic personality

Islamic personality is a consequence of the faith of a Muslim in his life. The Islamic personality of a person will appear on his mindset and pattern of attitude and also his pattern of behavior standardized to Islamic aqidah. A person who has a Muslim personality remains a man who does not escape the mistake, does not turn into an angel. Only when he did err, he immediately repented of repentance to God and corrected his shrine in accordance with Islam again.

\section{Mastering Islamic Tsaqofah}

The Word of Allah which means:

"Are you a more fortunate man, or a man who worships in the night time by prostration and standing, and is afraid of the hereafter, and expects the mercy of his lord? Say: "Are those people who know with people who don't know?" Indeed, a god-in-law who can receive lessons" (Q.S Az-Zuma: 9).

Unlike science, Tsaqofah is a science that is obtained not through experiments (experiments) but through news, notices, or mere conclusions. Tsaqofah Islam is a tsaqofah that arises because of the encouragement of one to be bound to Islam in his life. With Tsaqofah Islam, every Muslim can have a very strong footing to advance in life according to the direction of Islam.

\section{Mastering Science and Technology}

Allah says in the Quran: "Indeed, in the creation of the heavens and the earth, and the alternation of night and day there are signs for the people who are resourceful" (Q.S Ali-Imran: 190).

Mastering IPTEK is intended for Muslims to be able to perform its functions as the caliph of Allah SWT with good and optimal on the face of the earth. Islam even made it as Fardlu Kifayah, which is an obligation to be done by the people when the sciences are very needed people, such as medical science, industrial engineering, and others.

\section{Having Adequate Skills}

Allah says in the Quran:

"And prepare to face them of whatever power you are able to and from the horses which are inhibited to battle (which by that preparation) you are afraid of the enemy of God and thine enemies and people other than those whom you know not; Allah is knowing. Whatsoever thing you may tell in the way of God will undoubtedly be repaid to you, and you shall not be persecuted (harmed)" (Q.S Al-anfaal: 60). 
Mastery of all-material skills, such as skills in the industry of aviation and others, is also a claim that must be made by Muslims in the framework of the execution of his duties as the Caliph of God on the earth.

\section{Conclusion}

1. The basis of raising the child's independence is the Qur'an which is a clue for believers in all aspects. While the goal of raising the child's independence is so that the generation of Islam is not weak in knowledge.

2. Among the factors that can impede the independence of children, among others, family environmental factors, society and school.

3. Among the methods of drawing the child's self-reliance is the exemplary method, Targhip and Tarhib methods, and the Parable method.

4. The benefits of raising the children in the concept of Islamic education, among them to form the personality of Islam, master Tsaqofak Islam, Master Science and Technology (IPTEK), and possess adequate skills.

\section{References}

Abdurrahman, H. (1995). Compilation of Islamic law in Indonesia. Jakarta: CV. Akademika Pressindo. Ahmadi, D., \& Uhbiyati, N. (2001). Science of Islamic Education. Jakarta: Rineka Cipta.

Anita, L. (2004). Cooperative Learning: Practicing cooperatives Learning in classrooms. Jakarta: PT. Grasindo.

Arief, A. (2002). Introduction to Islamic Education science and methodology. Jakarta: Ciputat Press.

Clemes, H. Bean, R. (2001). Raising child self-esteem. Jakarta: the Premier partner.

Conger. (1997). Children's development and personality. Jakarta: Arcan

Department of National Education. (2007). Great Dictionary of Bahasa Indonesia. Jakarta: Department of Education and Culture.

Muhammad. (2008). Research methods. Bandung: library Setia.

Ghazali, M.A. (1997). Morals a Muslim. Bandung: Al-Ma'arif.

Gunawan, H. (2014). Character Education concept and implementation. Bandung: Afabeta.

Hidayati, N.A. (2013). Influence of method Storytelling on learning Qur'an Hadith in the formation of attitudes and behavior of students in MI Huda Maguan Kaliori Rembang. Thesis. Yogyakarta: UIN Sunan Kalijaga.

Marimba, A.D. (1974). Philosophy of Islamic education. Bandung: Al-Ma'arif.

Mastuhu. (1999). Empowering Islamic Education System. Jakarta: Logos Wacana Ilmu.

Munir, A. (2006). Spritual Teacbing. Yogyakarta: Pustaka Insan Madani.

Nata, A. (1997). Philosophy of Islamic education. Jakarta: Logos Discourse of Sciences.

Ramayulis. (2010). Islamic Religious education methodology. Jakarta: Kalam Mulia.

Saleh, A.A. (1994). Theory of education based on the Qur'an. Jakarta: Rineka Cipta.

Joseph, T. (1995). Islamic and foreign language teaching methodology. Jakarta: Raja Grafindo. 